\title{
Re-Engineering the Organization Based on Justice
}

\author{
Shabab Uddin Alamu ${ }^{1}$, Koes Indrati Prasetyo Rini ${ }^{2}$, Bambang Tri Cahyono ${ }^{3}$ \\ Urdu Federal University of Science and Technology, Islamabad, Pakistan ${ }^{1}$ \\ Faculty of Economics and Business, Pelita Bangsa University Cikarang, Indonesia ${ }^{2,3}$
}

Sonykhan031@gmail.com¹, koes.indrati@pelitabangsa.ac.id², bambangcahyono@pelitabanga.ac.id³

\begin{abstract}
The scope of the research is to discuss re-engineering strategic management based on justice to be limited by factors of strategic vision, mission, strategies, tactics, and efforts in relation to the values of God, humanity, unity of Indonesia or nationalism, democracy or democracy, and social justice or mutual cooperation. This research is limited by the management of social justice for all Indonesians through openness, togetherness, harmony, and tolerance. Furthermore, this research is limited by research locations in Jakarta and surrounding areas at the time of the study, which was 1-30 June 2020. Remembering that there was a significant difference between the re-engineering of conventional Organization businesses and Organization businesses based on social justice values injustice and this study proved that the application of social justice-based business management was better rather than conventional business management, it is suggested that the Organization change its business to be based on social justice values or a combination of social justice values and conventional values. Considering that there is a positive and significant influence on the re-engineering of the Organization business based on social justice values on the value of divinity, humanity, unity, democracy from the results of the field data tabulation it can be concluded that the influence of the social justice variable as an Organization business on other variables is significant at the 1 percent level, it is recommended that the Organization implement social re-engineering in the management of the Organization's strategy.
\end{abstract}

Keywords: Re-Engineering, Organization, Justice, Indonesia, Strategy

\section{Introduction}

Today the government's determination to carry out a mental revolution in human resources in the industrial era 4.0. the more it clearly rises to the surface. Various efforts have been made in the fields of education and culture, including through an independent learning program in primary and secondary schools and an independent campus in the world of higher education. This fundamental change is one of the conditions required in the re-engineering of the business of an organization such as an Organization. In addition to fundamental changes, the re-engineering of the Organization's business includes changes that are dramatic, radical and process. In the world of higher education, re-engineering included in the mental revolution of human resources is currently being studied, mainly related to the application of justice -based strategic management in the context of facing economic recession as a result of Covid-19. Re-engineering universities in Indonesia have relevance to the value of justice through tolerance to the principles of openness, togetherness, and continuity of business matching, aligned, and balanced. This research tries to find out how big is the relationship between the re-engineering of Organization businesses in Indonesia and the values contained in society. 
This research is motivated by the still low re-engineering of justice-based strategic management in Indonesia which is the object of research, especially on the re-engineering points as follows: The low application of the Organization's vision in incorporating elements of God values. Considering that the Organization's vision is an ideal or foresight that contains an element of uncertainty, the relationship with divine values should be very significant. In establishing the Organization's mission, it is necessary to note the relationship between missions with the implementation of strategic management in the principles humanity in behavior that is just, faithful, and humble through faith, love, and hope for the future of the Organization better. It would need to be upgraded anyway re-engineering strategic management is still low based on the principles unity in repentance, charity, and prayer improve gratitude, sincerity, and a blessing on national values.

Re-engineering management certain strategic tactics deemed universities is still low by use-values the basis of a populist who leads in consultative / representative. The Organization's tactics need to be improved through education, economics, laws in the family, community, a nation that is applied in the world of higher education. The low implementation of strategic management through efforts based on the values of justice still needs to be improved, especially through the tolerance of openness, solidarity, sustainability harmonious, and balanced in the world of higher education in Indonesia.

Based on the above background, this research intends to find out the extent to which Organization re-engineering can be done through dramatic changes from conventional strategic management, namely vision, mission, strategy, tactics, and efforts to become an Organization with the basic values of justice, namely the value of God, humanity, unity, society and social justice.

\section{Theoretical Framework}

The theoretical framework contains all the knowledge (theories, concepts, principles, laws and propositions) which can later help develop a conceptual framework and operational research. The findings of existing researchers are very helpful and facilitate researchers to create a conceptual framework. This conceptual framework is expected to provide a direct picture and assumptions regarding the variables to be examined.

Re-engineering the Organization's strategy is the total number of activities and choices needed to be able to carry out strategic planning. This strategy re-engineering is a process where several strategies and policies are transformed into actions through the development of programs, budgets, and procedures that are fundamentally, radically, dramatically, and in process. This research defines fundamentals as fundamental changes, like starting with a blank sheet of paper; radical as a rooted change from below; dramatically as productivity rises sharply; and proceed as a different treatment method. (see Hammer and Prahalad, 1990)

Strategic management is the highest management activity that is usually composed by the board of directors and carried out by the CEO and the executive team of the organization. Strategic management provides overall direction for the company and is closely related to the field of organizational behavior. Strategic management talks about the big picture. The essence of strategic management is to identify organizational goals, their resources, and how these available resources can be used most effectively to meet strategic objectives. Strategic management at this time must provide a basis or basic guidelines for 
decision making in the Organization. This is an ongoing and sustainable process, given that the application of an Organization re-engineering, should be sustainable in the long run.

The re-engineering of an organization is a living document that is always visited and re-visited. It might even be necessary to think of it as a liquid because of its ongoing nature to be modified. When new information is available, it must be used to make adjustments and revisions. Organization re-engineering is an activity or at least a hope that the Organization can change fundamentally, take root, be dramatic, and process through a number of key changes that are different from what has always been done so far.

Universities can take a position to meet various market needs, and in this case, the application of justice -based strategic management in the world of higher education will be able to meet the need for rapid improvement in the quality of human resources through the mental revolution of Organization stakeholders. This research tries to make a comparison between conventional Organization based strategic management with Organization strategic management re-engineering based on the application of justice values. With so many problems in the Organization world unresolved, it is hoped that the strategic re-engineering of justice-based universities will produce better solutions in the long run.

In implementing the re-engineering of justice -based universities, universities in certain regions can standardize their curriculum based on local needs that are different from the needs in big cities which usually prioritize profits through the basis of liberalism capitalism. For example, the Organization operates classes in crowded small cities, but with a population of fewer than 200,000 people. (Porter, 1985) Although a small market with purchasing capabilities under a big city, the Organization has managed to benefit from re-engineering with activities that are different from those offered by universities in big cities, for example by standardization, only opening a few special classes, and use the lower one learning technology than universities in big cities.

\subsection{Conceptual Framework}

The conceptual framework in this study is the relationship or link between one concept and another problem concept to be studied. This conceptual framework is useful for connecting or explaining at length about a topic that will be discussed. The topic to be discussed is how to apply the values of justice in Organization business in accordance with the prevailing rules of strategic management. By including the values of justice, it is expected that the Organization's performance will be better. Therefore this research wants to compare the vision, mission, strategy, tactics, and efforts of conventional universities with the application of justice-based strategies. This framework is derived from the concepts used as the basis of the research obtained in the literature review or is a summary of the literature review connected by lines in accordance with the variables studied as shown in the table below.

Table 1. Variabels

\begin{tabular}{ll}
\hline CONVENTIONAL VISION & RE-ENGINEERING VISION \\
CONVENTIONAL MISION & RE-ENGINEERING MISION \\
CONVENTIONAL TRATEGY & RE-ENGINEERING STRATEGY \\
CONVENTIONAL TACTICS & RE-ENGINEERING TACTICS \\
CONVENTIONAL EFFORT & RE-ENGINEERING EFFORT \\
\hline
\end{tabular}


This conceptual framework provides guidance to researchers in formulating research problems. Researchers will use the conceptual framework above to determine which questions must be answered by research respondents and what empirical procedures are used as tools to find answers to questions. In this study there are five tables, each of which consists of ten statements that must be answered by research respondents in the form of multiple choices with answers in the form of a Likert scale that has been prepared, namely 1 to disagree, 2 to disagree, 3 to agree and 4 for answers strongly agree. The conceptual framework in this study was obtained from the synthesis of deductive thought processes (application of theory) and inductive (existing facts, empirical), then with creative-innovative abilities, ending with a new concept or idea called the conceptual framework as contained in the flow chart above.

\subsection{Hypothesis}

a) There is a positive and significant relationship between social justice-based re-engineering with the re-engineering of the Organization's business strategy that is the value of togetherness, openness, continuity, harmony, and balance.

b) There is a positive and significant influence of re-engineering based on the value of social justice to the value of godliness, human values, the value of unity, and social values.

c) There is a comparison between indicators with and without Organization re-engineering that needs attention and priorities to be developed in the near future.

This research is very important in order to provide information to the general public and especially to Organization stakeholders about the re-engineering of the Organization's strategic management which consists of fundamental, radical, dramatic changes and processes on the Organization's vision, mission, strategy, tactics, and efforts. by including five basic values contained on the basis of the Indonesian state, namely the values of divinity, humanity, unity, society, and social justice.

\subsection{Literature Review}

The divine dimensions in the almighty God in this study include: The Organization claims its trust and devotion to Allah SWT; The Organization develops an attitude of respecting honor and support between adherents of different religions; Universities foster harmony among believers and belief in God Almighty; The Organization develops mutual respect for the freedom to practice worship in accordance with their respective religions and beliefs; The Organization does not impose religion and belief in Allah SWT on others.

Dimensions of Humanity in Humanity that are just and civilized in this study include: The Organization recognizes the equality of equality, equality of rights without differences in ethnicity, ethnicity, religion, beliefs, gender, social position; The Organization develops mutual respect for fellow human beings and an attitude of mutual tolerance and tolerance; The Organization develops a non-arbitrary attitude towards others; The Organization upholds evaluation values and likes to carry out successful activities; Universities dare to agree with truth and justice.

Dimensions in Indonesia Unity in this study include: the Organization was able to put unity, national and state interest above personal and group interests; Universities are able and willing to sacrifice for the sake of the nation and the nation is needed; The Organization develops a love for the motherland and the nation and pride in the nationality and land of Indonesia; The Organization participates in maintaining world order based on freedom, eternal 
peace, and social justice; The Organization develops Indonesian unity based on Unity in Diversity and advances associations for national unity and integrity.

The Dimensions of Democracy are led by wisdom in deliberations/representations in this study include: Universities prioritize deliberation in making decisions for the common good; The Organization conducts deliberations to reach consensus, which is overwhelmed by the spirit of the family; The Organization respects and upholds any decisions agreed upon as a result of deliberation; The Organization is responsible for accepting and carrying out the results of deliberations in the interests of the common good of personal and group interests; The Organization conducts deliberations with common sense in accordance with conscience and gives trust to representatives who are trusted to conduct deliberations.

The dimensions of social justice for all Indonesians in this study include: the Organization develops noble behavior, which reflects the attitudes and atmosphere of the family and mutual cooperation; Universities develop a justice attitude towards one another and maintain a balance between rights and obligations; Universities respect rights and provide assistance to others so that they can stand on their own; Universities do not use property rights for businesses that exploit other people and things that are luxurious and luxurious lifestyles; The Organization upholds the work of others who are beneficial to the progress and prosperity of a socially just society.

Below is a conceptual dimension based on justice as regulated in the People's Consultative Assembly (2001) as follows: Dimensions of social justice for all Indonesians. The Organization develops noble behavior, which reflects the attitude and atmosphere of the family and mutual cooperation. The Organization develops a justice attitude towards each other and maintains a balance between rights and obligations. Universities respect rights and provide assistance to others so that they can stand on their own. Universities do not use property rights for businesses that exploit other people and things that are luxurious lifestyles. The Organization upholds the work of others who are beneficial to the progress and prosperity of a socially just society.

\subsection{Related Studies}

AgusSutono (2015) states that the fundamental question in this research is, does the re-engineering of the nation's national education system already reflect a philosophical view rooted injustice? The writing method is a descriptive-analytic method and uses the hermeneutic method, then looks for the most relevant and primary data related to the study of justice and education and then conducts a sharper analysis so as to produce creative ideas. The results of this study include that the philosophy of justice education as the spirit of the national education system in Indonesia must really be lived as a source of values and references in strategic planning in the field of education in Indonesia.

The justice-based re-engineering philosophy must be implemented in a tangible and consistent manner so that the development of the Indonesian nation as mandated in the great ideals of the Indonesian nation can be achieved with the basic principles of justice values, namely the principle of religiosity, the embodiment and appreciation of human values, holding fast to the spiritual unity as a nation, the spirit of respecting differences and respecting democratic life and the embodiment of the values of justice, all of which must be realized through a dignified educational process.

Sudjito and TatitHariyanti (2018), stated that justice as a Scientific Paradigm for Studying Legal Pluralism in Indonesia: Literary Perspective, there is no common ground for perceptions of legal pluralism in Indonesia. Pros and cons to it are still found, both on a theoretical and 
practical level. This is often opposed by the unification of laws that can endanger national unity. Under the legal and literary movement, this paper is intended to promote the contribution of literature to sharing common ground for the study of legal pluralism in Indonesia. Using a literary point of view, legal products are analogous to literary products. A study of literary works will not be separated from the applied paradigm. One of the paradigms used is that the study of literary works will be interpreted from reality in society. The study of legal pluralism can be analogous to the study of various literary works.

The problem of pluralism and national law needs to be studied based on a system of values that are rooted in the life of the Indonesian nation, justice. From a literary perspective, justice deserves to be a scientific paradigm for studying legal pluralism in Indonesia. The values of justice are believed to be true and are used as guidelines in all activities of Indonesian life.

Zezen Zaenal Mutaqin (2016) The rights of every Indonesian citizen are protected by the 1945 Constitution. Is reality in accordance with normative regulations? Does democratization improve the protection of human rights especially in terms of religious freedom? We find that there is a difference between an ideal written constitution and reality. In this essay, he argues that the failure of the Indonesian democratic regime to protect human rights is a result of the lack of "justice". The ideal of "citizenship" refers to Fukuyama's idea of the ability of the state to plan and implement policies and enforce the law.

He delivered the argument that administrative weaknesses were caused by ambiguity in the interpretation of Indonesia's ideology, the Five Principles. This paper first discusses the idea of a strong state and its relationship to the protection of human rights. Along with examining concept theory, he will discuss the weaknesses of democratic regimes in Indonesia to protect human rights. This will be followed by an examination of the core arguments of this paper, arguing that the principle of causing weakness lies in the ambiguity of the government to interpret justice.

The implementation of strategic management based on justice is the only viable alternative if Indonesia wants to maintain its unity and diversity. In dealing with two conflicting ideologies, the solution offered by justice is that Indonesia will not become a secular state, where religion is absolutely separated by the state, or religion, where the state is governed by one particular belief. In short, both justice and secularization as differentiation enable us to avoid choosing between a secular state and a state with a narrow religion. So that this research has a foundation of literature and studies from within and outside the country which needs to be further developed in re-engineering higher education in Indonesia through 10 variables that will be further investigated.

\section{Methods}

\subsection{Research Design}

This research uses a survey research design. This research is included in quantitative research to examine the behavior of individuals or groups in the application of justice value-based management strategies. As an object of research, respondents were selected from two clusters representing two groups of students, namely undergraduate and postgraduate students. 
The determination of these two different clusters is intended to find out the differences in the response of undergraduate students who are generally young and the responses of postgraduate students who are generally certainly older and more mature than undergraduate students. In general, survey research uses questionnaires as a data collection tool. Survey research conducted is research that takes a sample from one population and uses a questionnaire as a primary data collection tool.

\subsection{Sampling Technique}

The sampling technique is a way to determine the number of samples according to the sample size to be used as the actual data source, taking into account population characteristics and distribution to obtain a representative sample. (Margono, 2004). Cluster Sampling used in this study is a group sampling technique. This type of sampling is done based on the group of respondents and specific areas. The respondent group consisted of a group of undergraduate students and a group of postgraduate students at Universities in the Jakarta area, Indonesia.

The researcher uses the Slovin formula where the number of respondents is the number of populations divided by one plus the population multiplied by the square of the standard error. Given that the total population is 400 students, it can be calculated the number of samples is: $400 / 1+400 \times 0,5 \times 0.5=200$ respondents.

\subsection{Data Collection Procedure}

Data collection in this study was conducted to obtain information needed to achieve the research objectives. Before conducting research, researchers have a hunch based on the theory used, that hunch is called a hypothesis. To prove the hypothesis empirically, researchers need to collect data for deeper examination. Although this research is only brief, researchers have had a long journey in the study of the application of the values of justice in everyday life (Cahyono, 2005). So that variables can be elaborated through research indicators that have long been observed by researchers.

The process of collecting data is determined by the variables in the hypothesis. Data collection was performed on a predetermined sample. Data is something that has no meaning for the recipient and still needs processing. Data can take a variety of forms, from images, sounds, letters, numbers, languages, symbols, and even circumstances. All of this can be referred to as data as long as it can be used in this study, so it can be used as material to see the environment, objects, events, or research concepts. The test is performed with SPSS software, with the following interpretation: for group decisions, variables are said to be reliable if they have an alpha reliability coefficient of 0.5 or more, while for individual decision making the allowable reliability is equal to 0.90 .

\subsection{Statistics Tool}

This research uses factor analysis which is one of the multivariate statistical techniques. The aim is to group data into groups according to the interrelationships between variables. In research applications, factor analysis can be used to determine individual groupings according to their characteristics, as well as to test the construct validity. In factor analysis, there are no dependent and independent variables. The process of factor analysis itself seeks to find relationships (interrelationship) between a number of variables that are 
interdependent with others so that one or several sets of variables can be made that are less than the initial number.

In the course of this research, analysis of the correlation is used to test construct validity. One way to test the construct validity can be done using factor analysis. Factor analysis will display the results of the extraction of question items into several components desired by the researcher. The principle used is the same, grouping data based on interrelations between items. An item is stated as a factor if the correlation value is greater than $(>=) 0.5$. Validity Factor Test. In this analysis, testing is done to see how much the correlation between one factor with other factors that form variables. If a strong correlation is found between the forming factors, then these factors are expressed as form variables. The magnitude of the correlation matrix commonly used is 0.5 .

\section{Results and Discussion}

\subsection{Description of Research Respondents}

Respondents in this study numbered 169 people with male and female gender consisting of 119 males and 50 females or 70.4 percent and 29.6 percent respectively. Male respondents were almost three times more than female respondents, indicating that the response of this study represented more rational answers. This study explores the opinions of the Occupation cluster consisting of Lecturers, Employees, and Students with a composition of 84 lecturers, 41 employees, and 44 students respectively, or 49.7 percent of lecturers, 24.3 percent of employees, and 26.0 students respectively. The composition of lecturers is half of the total respondents, indicating that the quality of respondents' answers represents mature and objective opinions and is relatively more accountable. This was confirmed by open interviews with several respondents who had experience and structural positions at the sample universities. They said that a justice-based strategy did need to be explored more and developed for a better Organization future.

This study divides the Age cluster into three age groups, namely the age group 18-24 years, 25-40 years, and 41 years and above with the number of each group being 48 young respondents, 54 adult respondents, and 67 elderly respondents. This research was conducted during the corona pandemic, where there were no lectures so that the number of young clusters became smaller than it should. In percentage, they consisted of 28.4 percent of young people, 32.0 percent of adult respondents, and 39.6 percent of parents. Considering that the majority of respondents are classified as adults and parents, it is certain that the quality of their answers reflects the opinions of experience that are quite long and based on the actual situation.

Profile of respondents based on the length of services cluster shows the length of time the respondent is serving or studying at the Organization, either as a lecturer, student, or student. They are grouped into three groups, namely the group serving 0-3 Years, 4-6 Years, and 7 Years or more with the number of respondents respectively 84 people, 52 people, and 33 people, or by 49.7 percent, 30.8 percent, respectively, and 19.5 percent. Respondents who worked and or studied at Organization for less than 3 years amounted to half of the total respondents. This number represents the real population, where most of them are employees, students and young lecturers. Besides that, in the last three years, many universities have recruited lecturers, employees and new students. 


\subsection{Validity and Reliability Tests}

This study aims to analyze five independent variables, namely the variable Vision (X1), Mission (X2), Strategy (X3), Tactics (X4), and Business (X5) Universities in Bekasi and surrounding districts involving 169 respondents. Testing the validity or suitability of the research variable data is carried out using the Pearson Correlation test with the following results:

Table 2. Test Validity of Research Variables

\begin{tabular}{cccc}
\hline Variable & Symbol & Pearson Correlation & Result \\
\hline Vision & X1 & 0846 & Valid \\
Mission & X2 & 0.929 & Valid \\
Strategy & X3 & 0.930 & Valid \\
Tactics & X4 & 0.882 & Valid \\
Effort & X5 & 0841 & Valid \\
\hline
\end{tabular}

From the results of the validity test on the five research variables above, it can be concluded that the five variables are valid because the value of each of them meets the validity threshold requirements, which is the same or above 0.700. Furthermore, testing of the reliability or consistency of the research variable data is carried out using the Cornbach's Alpha test. Testing is done to get the value of the validity threshold correlation, which is 0.600 as shown in the table below.

As for the Organization's Efforts, respondents rated agree with a score of 3,144 on a scale with a standard deviation of 0.398 and a variance of 0.159 . This means that there is an excess value of 0.144 points above the agreed value for the business effort that has been carried out. Management strategies based justice also has the advantage in the field Efforts strategy, where the conventional business, respondents given by 2,989 votes with standard deviation 0205 . As for the justice-based business, respondents gave a value of 3,199 with a standard deviation of 0.190 . Once again this research shows the superiority of justice based strategy management over conventional strategy management.

The research proposes 3 hypotheses, where the first hypothesis is about the closeness of the relationship and the real difference between the two indicators in the five variables, namely the Conventional Variable (CV) and the Variable of Equity (PV). Tests carried out using the Spearman Correlation on the correlation between Vision and Believe in God with the results $r=0.692(p=0.001)$ or have a strong correlation. Further testing of the closeness of the relationship between Mission and Humanism produces a value of $r=0.742$ with $p=0.001$ which means that the relationship between the two indicators is significant and very strong.

The close relationship between Strategy and Nationalism also occurs with the result $r=$ 0.633 or Strong and has $\mathrm{p}=0.001$ or significant at the level of 1 percent. As for the relationship between Tactics and Democracy, the result is $r=0.733$ or a very strong relationship with $\mathrm{p}=0.001$ or significant at the 1 percent level. Furthermore, for the relationship between Efforts and Social Justice, the value of $r=0.538$ or the relationship is strong with $\mathrm{p}=0.001$ or significant at the level of 1 percent.

Table 3. Esponse of Respondent

\begin{tabular}{ccccc}
\hline Hypothesis & $\begin{array}{c}\text { Variable } \\
\text { Conventional }\end{array}$ & $\begin{array}{c}\text { Variable } \\
\text { re-engineering }\end{array}$ & Spearman Correlation & Relationship \\
\hline Vision & Believe in God & $\mathrm{r}=0.692$ & Strong \\
\hline
\end{tabular}




\begin{tabular}{ccccc}
\hline Hypothesis & $\begin{array}{c}\text { Variable } \\
\text { Conventional }\end{array}$ & $\begin{array}{c}\text { Variable } \\
\text { re-engineering }\end{array}$ & Spearman Correlation & Relationship \\
\hline 1 & \multirow{2}{*}{ Mission } & Humanism & $\mathrm{p}=0.001$ & \\
& & $\mathrm{r}=0.742$ & Very strong \\
2 & Strategy & Nationalism & $\mathrm{p}=0.001$ & Strong \\
& & & $\mathrm{r}=0.633$ & \\
3 & Tactics & Democracy & $\mathrm{r}=0.001$ & Very strong \\
& & & $\mathrm{p}=0.001$ & Strong \\
& \multirow{2}{*}{ Efforts } & Social Justice & $\mathrm{r}=0.538$ & \\
\hline
\end{tabular}

\subsection{Hypothesis 1 Test Results}

There is a significant difference between the re-engineering of conventional Organization ventures and Organization ventures based on the value of social justice. Researchers suspect that the Organization's business based on the basic value of social justice has a higher value compared to conventional Organization businesses. This study examines the above hypothesis by using a comparison between justice Value (PV) and Conventional Value (CV). where Negative Ranks or PV $<\mathrm{CV}$ expressed by as many as $14(8.3 \%)$ respondents with a mean of 46.36 and Positive Ranks where PV> CV is supported by 119 (70.4\%) respondents with a mean value of 68.43 . This value is the highest among other strategic values.

The respondents who stated there was no difference between VP and CV or PV $=\mathrm{CV}$ was $36(21.3 \%)$ respondents. The results of this study are supported by a $Z$ value of $-8,567$ which is significant at a $1 \%$ level based on the negative Wilcoxon Signed Ranks Test. Thus it can be concluded that a Organization-based justice business is significantly better than a conventional Organization business.

Table 4. Comparison Between Justice- Based (Pv) and Businesses Conventional Business (Cv)

\begin{tabular}{ccccc}
\hline Ranks & Meaning & Response & The mean & Z-Test \\
\hline Negative Ranks & $\mathrm{PV}<\mathrm{CV}$ & $14(8.3 \%)$ & 46.36 & $-8,567 * * *$ \\
Positive Ranks & $\mathrm{PV}>\mathrm{CV}$ & $119(70.4 \%)$ & 68.43 & Note: $* * *$ is significant at 1\% level \\
Ties & $\mathrm{PV}=\mathrm{CV}$ & $36(21.3 \%)$ & \multicolumn{2}{c}{ Ranks Test } \\
Total & & $169(100 \%)$ & \multicolumn{2}{c}{ based on negative Wilcoxon Signed } \\
\hline
\end{tabular}

\subsection{Hypothesis 2 Test Results}

There is a positive and significant influence on the re-engineering of the Organization business based on social justice values on the value of God, humanity, unity, democracy. To test this hypothesis, this study uses linear regression analysis to determine the effect of social justice efforts on the value of other justice-based strategies. From the results of the field data tabulation it can be concluded that the influence of the social justice variable as an Organization business on other variables is significant at the 1 percent level with the following details: 
The social justice variable has a positive and significant effect at the level of 1 percent to the God variable with the magnitude of the constant value and the beta coefficient of 1.35 and 0.64 , respectively. This means that if the social justice coefficient value is zero, then the God variable value is 1.35 and if the social justice variable coefficient value increases I scale units, then the God value will increase by 0.64 scale units. The democracy variable explains 34 percent of the divine variable, while the remaining 66 percent is explained by other variables outside the regression equation system.

The social justice variable has a positive and significant effect at the level of 1 percent to the human variable with a constant value of the beta and coefficient of 0.88 and 0.75 , respectively. This means that if the value of the social justice coefficient is zero, then the value of the humanitarian variable is 0.88 and if the coefficient value of the social justice variable increases I to the scale unit, then the value of the humanitarian mission variable will increase by 0.75 scale units. The social justice variable explains 56 percent of the humanitarian variable, while the remaining 44 percent is explained by other variables outside the regression equation system.

The social justice variable has a positive and significant effect at the level of 1 percent on the nationalism variable with the magnitude of the constant value and the beta coefficient of 0.83 and 0.80 , respectively. This means that if the value of the social justice coefficient is zero, then the value of the nationalism variable is 0.83 and if the coefficient value of the social justice variable increases by 1 unit of scale, then the value of the nationalism strategy within the Organization will increase by 0.80 units of scale. The social justice variable explains 53 percent of the democratic variable, while the remaining 47 percent is explained by other variables outside the regression equation system. The social justice variable has a positive and significant effect on the level of 1 percent of the democratic variable with the magnitude of the constants and beta coefficients of 0.59 and 0.82 . the increase 1 scale units, then the value of democracy will increase by 0.82 scale units. The social justice variable explains 63 percent of the social justice variable, while the remaining 37 percent is explained by other variables outside the regression equation system.

Table 5. Result of Justice Based Re-Engineering

\begin{tabular}{cccccc}
\hline $\begin{array}{c}\text { Independent } \\
\text { Variable }\end{array}$ & $\begin{array}{c}\text { Dependent } \\
\text { Variable }\end{array}$ & Constant & Beta & F-test & $\mathbf{R}^{2}$ \\
\hline & Believe in God & 1.35 & 0.64 & $87.15 * * *$ & 0.34 \\
& & $(5.92)^{* * *}$ & $(9.34)^{* * *}$ & & \\
Social Justice & 0.88 & 0.75 & $212.88 * * *$ & 0.56 \\
& Numanism & $(5.14)^{* * *}$ & $(! 4.59)^{* * *}$ & & \\
& 0.83 & 0.80 & $190.49 * * *$ & 0.53 \\
& Nationalism & $(4.33)^{* * *}$ & $(13.80)^{* * *}$ & & \\
& Democracy & $(3.63)^{* * *}$ & $(16.77)^{* * *}$ & $282.29 * * *$ & 0.63 \\
\hline & Note: Numbers in Parentheses are t statistics. *** means Significant at $1 \%$ level
\end{tabular}

\subsection{Hypothesis Test Results 3}

This study compares justice value (PV) based business and conventional value (CV) among the five indicators that have the highest value based on Principal Component Analysis scores derived from Factor Analysis through the SPSS Program, with the following results and analysis: 
The Organization practices the value of justice and upholds the principle of togetherness in business by taking joint risks and providing equitable welfare for stakeholders. The Organization applies the value of social justice and sustainability in the long run by adhering to the principle of openness in every important decision-making. The Organization applies the value of social justice in the field of academic and professional education, through the open and transparent distribution of curriculum and study programs. The Organization applies the value of social justice in the field of research in general and maintains the business ethics of research and implementation in accordance with applicable regulations. The Organization applies the value of social justice in coordinating with third parties by prioritizing a win-win solution for all parties involved.

The conventional strategy-based businesses that get high scores in the Principal Component Analysis are also presented below as a comparison of justice -based businesses, even though respondents' judgments give higher values to justice value-based businesses as shown in the table below. The Organization makes an effort to maximize income from student education contributions with efforts to gain long-term benefits. The Organization makes an effort to seek optimal profit. Every time a study program is opened to the people who need it.

The Organization makes an effort to seek profit in the academic field by paying attention to the ability to pay the local community. The Organization makes an effort to seek profits in the field of research, especially commercial and commercial research for the long-term sustainability of the business. The Organization makes an effort to seek profits in the field of community service, especially through cooperation with the business world and the industrial world.

Table 6. Comparative Analysis of Organization Business

\begin{tabular}{|c|c|c|c|c|c|}
\hline Symbol & $\begin{array}{c}\text { With } \\
\text { Re-Engineering }\end{array}$ & PCA & Symbol & $\begin{array}{c}\text { Without } \\
\text { Re-Engineering }\end{array}$ & PCA \\
\hline X521 & $\begin{array}{l}\text { The Organization practices the } \\
\text { value of justice and upholds the } \\
\text { principle of togetherness in } \\
\text { business }\end{array}$ & 0.683 & X512 & $\begin{array}{l}\text { The Organization makes an } \\
\text { effort to maximize income } \\
\text { from student education } \\
\text { contributions. }\end{array}$ & 0.643 \\
\hline X522 & $\begin{array}{l}\text { The Organization applies the value } \\
\text { of social justice and sustainability } \\
\text { in the long run. }\end{array}$ & 0.735 & X515 & $\begin{array}{l}\text { The Organization makes an } \\
\text { effort to find optimal profits. }\end{array}$ & 0.657 \\
\hline X524 & $\begin{array}{l}\text { The Organization applies the value } \\
\text { of social justice in the field of } \\
\text { academic and professional } \\
\text { education. }\end{array}$ & 0.697 & X516 & $\begin{array}{l}\text { The Organization makes an } \\
\text { effort to seek profits in the } \\
\text { academic field. }\end{array}$ & 0.802 \\
\hline X525 & $\begin{array}{l}\text { The Organization applies the value } \\
\text { of social justice in the field of } \\
\text { research in general. }\end{array}$ & & X517 & $\begin{array}{l}\text { The Organization makes an } \\
\text { effort to seek profits in the } \\
\text { field of research. }\end{array}$ & 0.666 \\
\hline X528 & $\begin{array}{l}\text { The Organization applies the value } \\
\text { of social justice in coordinating } \\
\text { with third parties. }\end{array}$ & 0704 & X518 & $\begin{array}{l}\text { The Organization makes an } \\
\text { effort to seek profits in the } \\
\text { field of community service. }\end{array}$ & 0707 \\
\hline
\end{tabular}

From the results of the research presented in the 21 tables above, it can be concluded that this study has several important discussions that can be conveyed to stakeholders in this country. Discussion of the benefits of research that can be drawn from this study include:

The problem of the efforts of the Indonesian people has always led to the problem of not yet achieving social justice for all Indonesian people who are currently far from being grilled. Social justice can only be achieved by practicing the values of justice based on 
openness, togetherness, and continuity to produce harmonious, harmonious, and balanced social justice.

Every effort based on the value of social justice can be achieved through national leadership that is in favor of the interests of the nation and the state above personal interests and party interests. Therefore this country must be led by heads of states who are not a party and who are able to stand above all existing parties. The head of state must have a policy that is open in running the government, togetherness in dealing with every nation's problems and carrying out the people's mandate on an ongoing basis. In the end, social justice is a right and obligation for all Indonesian citizens to realize it. However, on the way to that direction, there must be implementation instructions in the form of academic texts containing clear methodology and rules.

Educational institutions such as universities are needed in collaboration with other institutions that have a track record in giving birth to a justice-based management strategy to follow up on management. This justice strategy is a solution to the economic problems of the nation and the state of Indonesia. If necessary, a Justice -based Strategy Management Strategy is implemented as mandated by Article 33 of the Constitution of the Republic of Indonesia.

The Organization was founded by community leaders and other champions of higher education. Their pioneering work was continued by an energetic and competent young generation in their field, all of whom were competent to carry out their profession in guarding the realization of justice management to be practiced in this country. If it can be agreed that justice-based management strategies are relevant to fight for in order to overcome all the economic problems of the nation and the state of Indonesia, then this study recommends the determination to unite to be the pioneers of the nation to fight for the re-engineering based on justice to become a real practice with stakeholders and authorities. Revive the fighting spirit that has been inherited from previous fighters as a mandate for the suffering of the people who have long suffered and revive their economy by siding with social justice for the whole of the Indonesian people.

\section{Conclusion}

There is a significant difference between the re-engineering of conventional Organization businesses and Organization businesses based on the value of basic social justice where PV> CV supported by 119 (70.4\%) respondents with a mean value of 68.43 proves that the application of social justice-based business management is better than management conventional business. There is a positive and significant influence on the re-engineering of the Organization business based on the value of social justice to the value of God, humanity, unity, democracy. From the results of the field data tabulation, it can be concluded that the effect of the social justice variable as an Organization re-engineering base on other variables is significant at the 1 percent level.

\section{References}

[1] AgusSutono (2015), Strengthening justice as a National Education Philosophy, paper in HTTP: // journals. upgris.ac.id/index.php / civic / article / view / 628 
[2] Bambang Tri Cahyono (2005), Perfect Life Strategy, Strategic Spiritual Quotient, SSQ International Publisher, Jakarta

[3] Hammer and Prahalad (1995), Re-engineering the Corporation, McGraw Hill Book Company, New York

[4] Herman Ruslim, 2016, Attitude and Job Satisfaction, PowerPoint Seminar, Jakarta

[5] Porter, Michael, 1995, Competitive Advantage, Erlangga Publisher, Surabaya

[6] David, Fred R. (2004). Strategic Management: Concepts (Ninth Edition). Gramedia Group Index PT. ISBN 979-683-700-5.

[7] Ketchen Jr. D. et all. (2009). "2008-2009 Strategy". New York: McGraw-Hill

[8] Porter, Michael (1996). "What is Strategy?" Harvard Business Review p. 61-79

[9] Sudjito and TatitHariyanti (20180, justice as a Scientific Paradigm to Discuss Legal Pluralism in Indonesia: Literary Perspective, First International Conference on Law, Governance and Social Justice (ICoL GAS 2018)

[10] ZezenZaenalMutaqin (2016) Strong State and justice: Reflecting Human Rights in Indonesian Democracy Constitutional Review, December 2016, Volume 2, Number 2 